\title{
PRODUKSI KARKAS DAN KUALITAS FISIK DAGING KELINCI LOKAL YANG DIBERI KONSENTRAT DENGAN LEVEL PROTEIN BERBEDA
}

\author{
Johanis L. Rihi' \\ INTISARI
}

Penelitian ini bertujuan untuk mengetahui produksi karkas dan kualitas fisik daging kelinci lokal yang diberi konsentrat dengan level protein berbeda. Penelitian ini dilaksanakan dikandang pemeliharaan di kelurahan Penfui, kecamatan Maulafa, kota Kupang sejak tanggal 25 Mei sampai 25 Agustus 2002 menggunakan dua belas ekor kelinci lokal jantan berumur $4-5$ bulan dengan bobot badan awal $1400-1500 \mathrm{~g}$. Analisis kualitas daging menggunakan otot Longissimus dorsi dan Biceps femoris di laboratorium Teknologi Hasil Ternak Fakultas Peternakan Universitas Nusa Cendana Kupang. Perlakuan pakan yang diberikan adalah : pakan dasar limbah kangkung; konsentrat dengan level protein masing-masing $\mathrm{R} 1=9 \% ; \mathrm{R} 2=12 \% ; \mathrm{R} 3=15 \%$ dan $\mathrm{R} 4=18 \%$. Limbah kangkung dan air minum diberikan secara ad libitum. Rancangan percobaan yang digunakan adalah rancangan acak lengkap (RAL) dengan 4 perlakuan dan 3 ulangan. Analisis data dengan analisis variansi dan uji jarak berganda Duncan's. Hasil penelitian menunjukkan bahwa pemberian konsentrat dengan level protein berbeda berpengaruh nyata terhadap bobot karkas, bobot daging, daya ikat air dan susut masak daging kelinci. Bobot karkas tertinggi $(\mathrm{P}<0,05)$ adalah $970,00 \mathrm{~g}(\mathrm{R} 4)$ kemudian R3; R2; dan R1 masing-masing $823,33 \mathrm{~g} ; 796,67 \mathrm{~g}$ dan $793,33 \mathrm{~g}$. Bobot dan persentase daging berbeda nyata $(\mathrm{P}<0,05)$ masing-masing untuk R4; R3; R2; dan R1 adalah 733,33g(77,66\%); 633,33g $(76,90 \%) ; 611,66 \mathrm{~g}$ $(76,74 \%)$; dan $606,66 \mathrm{~g}(76,48 \%)$. Persentase karkas, bobot dan persentase tulang serta keempukan berbeda tidak nyata diantara keempat perlakuan. Kualitas fisik daging, yaitu daya ikat air tertinggi R4; $43,90 \%(\mathrm{P}<0,05)$, kemudian R3; R2; dan R1; adalah 38,63\%;36,97\%; dan $35,57 \%$; Susut masak semakin menurun dengan meningkatnya level protein pakan $\mathrm{R} 4 ; 26,67 \%(\mathrm{P}<0,05)$ kemudian $\mathrm{R} 3$; R2; dan $\mathrm{R} 1$ adalah $33,13 \% ; 33,20 \%$ dan $34,30 \%$.

(Kata kunci : Kelinci lokal, Level protein, Produksi karkas, Kualitas daging).

Buletin Peternakan 28 (2): $65-71,2004$

'Fakultas Peternakan Universitas Nusa Cendana, Kupang. 


\section{CARCASS PRODUCTION AND PHYSICAL QUALITY OF LOCAL RABBIT MEAT FED CONCENTRATE WITH DIFFERENT PROTEIN LEVELS}

\section{ABSTRACT}

This research was aimed to know carcass production and physical quality of local rabbit meat fed with concentrates of different protein levels. This research was conducted in rearing stables at Penfui village, sub district of Maulafa Kupang city from May $25^{\Delta}$ to August $25^{\text {th }} 2002$. Twelve local male rabbits aged 4-5 months with initial body weight of $1400-1500$ g were used in this research. The analysis of meat quality was conducted with Longissimus dorsi muscle and Biceps femoris muscle at the laboratory of anintal product technology of Animal Science Faculty of Nusa Cendana University Kupang. The treatments were Kangkung rubbish / by product as the main feeding, supplemented with concentrates containing different protein levels of $9 \% ; 12 \% ; 15 \%$; and $18 \%$ namely R1; R2; R3; and R4. Kangkung rubbish and drinking water were given ad libitum. Completely Randomized Design was applied with four treatments and three replications. Analysis of Variance was used to analyse data and Duncan's test was applied. The results of the research indicated that supplementation with different protein levels of concentrate influenced significantly $(\mathrm{P}<0.05)$ on carcass and meat weight, water holding capacity and cooking loss of rabbit meat. The highest carcass weight was $970.00 \mathrm{~g}$ (R4) and then R3; R2; and R1 of $823.33 \mathrm{~g} ; 796.67 \mathrm{~g}$; and $793.33 \mathrm{~g}$ respectively. The actual meat weight and meat percentage were significantly different $(P<0.05)$. The highest weight and meat percentage were found on R4 (733.33g and $77.66 \%$ ) and followed by ; R3; R2; and R1, by $633.33 \mathrm{~g}(76.90 \%) ; 611.66 \mathrm{~g}(76.74 \%)$; and $606.66 \mathrm{~g}(76.48 \%)$ respectively. Dressing percentage, weight and bone percentage and shear press were not significantly different among treatments. Water holding capacity was significant $(\mathrm{P}<0.05)$ with $\mathrm{R} 4 ; 43.90 \%$ the highest and followed by $\mathrm{R} 3$; R2; and $\mathrm{R} 1$ of $38.63 \% ; 36.97 \%$; and $35.57 \%$ respectively. Cooking loss tended to decline as protein levels increased. It was significantly different $(\mathrm{P}<0.05)$ with the lowest cooking loss was on $\mathrm{R} 4 ; 26.67 \%$ and followed by R3; R2; and R1 namely $33.13 \% ; 33.20 \%$; and $34.30 \%$ respectively.

(Key words: Local rabbit, Proten levels, Carcass production, Meat quality).

\section{Pendahuluan}

Berbagai upaya untuk meningkatkan produksi ternak (produksi daging) sebagai sumber protein hewani dalam rangka memenuhi kebutuhan konsumen telah banyak dilakukan. Meningkatnya kebutuhan akan protein hewani sebagai zat pembangun tubuh tersebut seiring dengan meningkatnya jumlah penduduk, pendapatan per kapita, daya beli, pola hidup serta kesadaran masyarakat akan pentingnya gizi. Kondisi tersebut mengharuskan tersedianya daging dalam jumlah dan mutu yang memadai. Pemenuhan kebutuhan akan daging selalu bergantung pada daging sapi, kerbau, kambing, domba, babi dan ayam.

Altematif lain yang dapat dilakukan adalah ternak kelinci yang juga memiliki kemampuan produksi tinggi, cepat berkembang biak dengan jumlah anak per kelahiran tinggi, selang waktu kelahiran singkat. Selain itu, pakan kelinci mudah diperoleh dan harganya murah, tidak berkompetisi dengan kebutuhan manusia, mudah pemeliharaannya sehingga tidak membutuhkan modal awal yang besar untuk mengusahakannya, namun cepat berproduksi (Blakely dan Bade, 1991). Kelinci memiliki potensi besar dalam memproduksi daging yang sangat diperlukan untuk memenuhi permintaan yang semakin meningkat (Sofyadi, 1984). Keunggulan yang dimiliki ternak kelinci yakni, dapat menghasilkan daging berkualitas tinggi dengan kadar lemak rendah, serta persentase tulangnya juga relatif lebih rendah (Rismunandar, 1986).

Potensi dan peluang ternak kelinci seperti tersebut di atas, dapat dicapai secara optimal jika didukung dengan pemberian pakan yang memadai sesuai kebutuhan baik jumlah maupun mutunya. Kebutuhan tersebut baik untuk mempertahankan hidupnya, berproduksi maupun untuk reproduksi. Penyediaan pakan sebaiknya dari bahan-bahan yang mudah 
didapat dan tersedia secara terus menerus, palatabel, tidak menimbulkan efek negatif, serta mengandung zat-zat nutrisi yang memadai untuk kebutuhan ternak kelinci. Pada umumnya pakan utama ternak kelinci adalah hijauan berupa rerumputan dan daun-daunan, diantaranya adalah kangkung (Ipomoea reptans) yang dapat pula diberikan dalam bentuk limbah.

Untuk mencapai pertumbuhan dan produksi yang optimal, dalam, pakan kelinci perlu ditambahkan konsentrat berupa biji-bijian maupun produk asal hewan seperti tepung ikan. Jenis biji - bijian yang biasanya diberikan adalah jagung yang memiliki kandungan protein $5-9 \%$. Biji saga pohon dengan kadar protein $17-18 \%$ dapat dikombinasikan dengan biji jagung sebagai konsentrat dalam pakan kelinci. Selain itu, tepung ikan juga merupakan sumber protein dan mineral yang baik ditambahkan dalam pakan ternak kelinci untuk pertumbuhan dan produksi (Rasyaf, 1994). Pemberian ransum yang mengandung kadar protein tinggi pada kelinci muda dapat meningkatkan laju pertumbuhan sebesar $13-25$ $\%$ dan meningkatkan efisiensi penggunaan ransum 20 sampai $25 \%$ bagi pertambahan bobot badan (Casady, et al, 1971). Peningkatan protein ransum dari $12,2 \%$ hingga $16,3 \%$ dalam ransum kelinci dapat meningkatkan konsumsi ransum dan pertambahan bobot badan (Arrington and Kelley, 1976). Perlu pula diperhatikan bahwa kecukupan protein dalam pakan sangat mempengaruhi pertumbuhan dan perkembangan serta produksi daging. Kekurangan protein dalam ransum menyebabkan rendahnya konsumsi dan efisiensi ransum dan kelebihan protein menyebabkan menurunnya efisiensi penggunaan ransum tersebut (Prawiro-kusumo, 1993).

Karkas merupakan hasil pemotongan ternak dengan komponen utama adalah daging, tulang dan lemak. Perimbangan atau perbandingan antara ketiga komponen tersebut merupakan gambaran dari kualitas karkas, (Soeparno, 1992). Selanjutnya dinyatakan bahwa persentase daging yang tinggi, tulang dan lemak yang rendah merupakan salah satu indikator kualitas karkas yang baik. Imbangan daging dan tulang dari karkas yang baik adalah 5:1 yang diperoleh dari persentase karkas 55\% (Calvert, 1973). Selain itu, kualitas daging merupakan informasi yang penting dan sangat berperan dalam menarik minat konsumen untuk mengkonsumsinya.

Kualitas daging diartikan sebagai kombinasi sifat khas baik fisik, struktural maupun kimia daging sehingga berpenampilan baik sebagai bahan pangan (Lawrie, 1979). Secara fisik, daging didefinisikan sebagai semua jaringan hewan dan semua produk hasil pengolahan jaringan tersebut yang sesuai untuk dimakan serta tidak menimbulkan gangguan kesehatan bagi yang memakannya (Soeparno, 1992). Sifat- sifat fisik daging dapat menentukan kualitas daging dengan mengukur daya ikat air, susut masak serta keempukan daging (Lawrie, 1979). Oleh karena itu penelitian ini bertujuan untuk mempelajari produksi karkas yaitu (bobot dan persentase karkas, bobot dan persentase daging termasuk lemak yang melekat pada daging, bobot dan persentase tulang serta kualitas fisik daging yaitu (daya ikat air, susut masak dan keempukan) daging kelinci yang diberi konsentrat dengan level protein berbeda. Hasil penelitian ini diharapkan ${ }^{4}$ dapat bermanfaat sebagai informasi ilmiah untuk pengembangan ternak kelinci sebagai sumber produksi daging atau sumber protein hewani.

\section{Materi dan Metode}

Penelitian ini dilakukan selama 4 bulan (bulan Mei - Agustus 2002) di kandang percobaan Kelurahan Penfui, Kecamatan Maulafa, Kota Kupang untuk perlakuan pakan dan di Laboratorium Teknologi Hasil Ternak Fakultas Peternakan Undana untuk analisis kualitas daging. Dalam penelitian ini digunakan 12 ekor kelinci lokal jantan yang berumur 4 - 5 bulan dengan berat badan awal $1400-1500 \mathrm{~g}$. Menggunakan kandang individu masing masing berukuran $60 \times 50 \times 60 \mathrm{~cm}$. Ransum pakan yang digunakan adalah limbah kangkung sebagai pakan dasar, konsentrat yang terdiri dari jagung giling, tepung biji saga dan tepung ikan dengan formula ransum yang diberikan : $\mathrm{R} 1=$ limbah kangkung + konsentrat dengan level protein $9 \%, \mathrm{R} 2$ = limbah kangkung + konsentrat dengan level protein $12 \%$, R3 = limbah kangkung + konsentrat dengan level protein $15 \%$ dan R4 = limbah kangkung + 
konsentrat dengan level protein $18 \%$. Limbah kangkung dan air minum diberikan secara adlibitum. Kelinci dipotong pada akhir masa penelitian dengan perlakuan diistirahatkan selama $10 \mathrm{jam}$. Setelah pemotongan, dilakukan penimbangan karkas dan pemisahan komponen -komponen karkas yaitu daging (termasuk lemak yang melekat pada daging) dan tulang. Sampel daging untuk analisis kualitas daging diambil dari otot Biceps femoris dan otot Longisimus dorsi, dengan prosedur analisis kualitas daging menurut prosedur Hamm (Soeparno, 1992). Variabel yang diamati menggunakan rancangan acak lengkap (RAL) dengan 4 perlakuan dan 3 ulangan. Jika terdapat perbedaan diantara variabel yang diamati dilanjutkan dengan uji jarak berganda Duncan (Steel dan Torrie, 1993).

\section{Hasil dan Pembahasan}

\section{Bobot dan persentase karkas}

Tingkat produksi karkas, produksi daging, dan produksi tulang, sebagai komponen utama karkas merupakan indikator kualitas karkas. Bobot dan persentase karkas kelinci hasil penelitian disajikan dalam Tabel 1.

Bobot karkas tertinggi dicapai oleh kelinci yang memperoleh perlakuan protein dengan level $18 \%(\mathrm{R} 4)$ berbeda nyata $(\mathrm{P}<0,05)$. Hasil analisis statistik menunjukan perlakuan berpengaruh nyata. Hal ini menunjukkan bahwa semakin tinggi level protein yang dikonsumsi maka semakin tinggi pula bobot karkas yang diperoleh.

Uji lanjut DMRT menunjukan bahwa pasangan perlakuan R4 - R1, R4 - R2 dan R4 R3 berbeda nyata $(P<0,05)$ sedangkan antara pasangan-pasangan perlakuan lainnya berbeda tidak nyata. Keadaan tersebut dapat dinyatakan bahwa perlakuan R4 merupakan perlakuan yang terbaik dalam meningkatkan bobot karkas.

Persentase karkas tidak seiring dengan peningkatan level protein yang diberikan serta tidak terdapat perbedaan nyata antar perlakuan. Keadaan tersebut diduga karena banyaknya isi saluran pencernaan yang tersisa ketika ternak dipotong atau juga berat non karkas yang ikut meningkat karena kelinci masih dalam masa pertumbuhan. Persentase karkas banyak dipengaruhi oleh tingkat bobot potong dan lebih kecil pengaruhnya oleh nutrisi
(Soepamo, 1992). Peningkatan bobot potong dapat meningkatkan bobot karkas akan tetapi persentase karkas tidak selamanya ikut meningkat (Sents et al., 1982). Walaupun persentase karkas yang tidak menunjukkan perbedaan nyata $(P>0,05)$, namun demikian terlihat bahwa persentase karkas cenderung meningkat dengan peningkatan level protein pakan $(\mathrm{R} 4=51,99 \%)$.

Rata-rata bobot daging kelinci yang mendapat perlakuan protein dengan level $18 \%$ (R4), adalah yang tertinggi $(753,33 \mathrm{~g})$ dibanding dengan perlakuan lainnya. Hasil analisis statistik menunjukkan perlakuan berpengaruh nyata $(\mathrm{P}<0,05)$. Hal tersebut menunjukkan pula bahwa semakin tinggi level protein yang diberikan berarti semakin tinggi pula bobot daging yang dihasilkan. Uji jarak berganda menunjukkan bahwa pasangan perlakuan R4 - R1, R4 - R2, dan R4 - R3 berbeda nyata $(\mathrm{P}<0,05)$, sedangkan antara perlakuan lainnya berbeda tidak nyata.

Hasil penelitian menunjukkan bobot dan persentase daging meningkat dengan meningkatnya level protein pakan yaitu pada perlakuan $\mathrm{R} 4 ; 753,33 \mathrm{~g}(77 ; 66 \%)$ dibanding dengan perlakuan lainnya. Tingginya persentase daging yang diperoleh selain karena pengaruh level protein, juga disebabkan oleh persentase tulang yang semakin stabil bahkan menurun sesuai dengan pertumbuhan tubuh.

Pertumbuhan tubuh secara keseluruhan adalah resultan dari pertumbuhan bagianbagian tubuh, dimana tulang-tulang tumbuh dengan cepat dan dalam jangka waktu yang relatif singkat setelah hewan dilahirkan (Anggorodi dan Wahyu, 1969). Tulang merupakan bagian karkas yang perkembangannya lebih dahulu dibanding dengan perkembangan urat daging dan lemak, tumbuh lebih lambat dan akan semakin menurun dengan meningkatnya umur ternak sehingga urat daging menjadi komponen yang relatiflebih besar (Cole dan Lawrie, 1974) Hasil analisis statistik menunjukkan bahwa perlakuan berpengaruh nyata $(P<0,05)$. Uji jarak berganda pada bobot daging, pasangan R4 - R3, R4 - R2, dan $R 4$ - $R 1$ berbeda nyata $(P<0,05)$ sedangkan antara perlakuan- perlakuan lainnya berbeda tidak nyata. Persentase daging, antara pasangan $\mathrm{R} 4$ - R1 berbeda sangat nyata $(\mathrm{P}<0,01), \mathrm{R} 4-\mathrm{R} 2$ dan $R 4-R 3$ berbeda nyata $(P<0,05)$ sedangkan 
Tabel 1. Rata-rata bobot karkas dan persentase karkas

(Weight and percentage of carcasses of rabbit)

\begin{tabular}{clcccc}
\hline $\begin{array}{c}\text { Level protein } \\
\begin{array}{c}\text { (Protein level) } \\
(\%)\end{array}\end{array}$ & \multicolumn{1}{c}{ Peubah (Parameter) } & \multicolumn{3}{c}{ Ulangan (Replication) } & Rata-rata \\
\cline { 3 - 5 } (Average)
\end{tabular}

${ }^{a, b}$ Huruf yang berbeda pada kolom yang sama menunjukkan perbedaan nyata $(\mathrm{P}<0,05)$ (Different superscript in the same column showed significant difference $(P<0.05)$ ).

Tabel 2. Rata-rata bobot daging dan persentase daging, bobot tulang dan persentase tulang (Weight and percentages of meat, and weight and percentages of bone of rabbit)

\begin{tabular}{|c|c|c|c|c|c|}
\hline \multirow{2}{*}{$\begin{array}{c}\text { Level protein } \\
\text { (Protein level) } \\
(\%)\end{array}$} & \multirow[t]{2}{*}{ Peubah (Parameter) } & \multicolumn{3}{|c|}{ Ulangan (Replication) } & \multirow{2}{*}{$\begin{array}{l}\text { Rata-rata } \\
\text { (Average) }\end{array}$} \\
\hline & & 1 & 2 & 3 & \\
\hline \multirow{4}{*}{$\begin{array}{c}9 \\
\text { (R1) }\end{array}$} & Bobot daging (Meat weight) (g) & 645 & 615 & 560 & $606,66^{\mathrm{a}}$ \\
\hline & $(\%)$ & 75,88 & 76,87 & 76,71 & $76,48^{\mathrm{a}}$ \\
\hline & Bobot tulang (Bone weight) $(\mathrm{g})$ & 155 & 145 & 130 & 143,33 \\
\hline & $(\%)$ & 18,23 & 18,12 & 17,80 & 18,05 \\
\hline 12 & Bobot daging (Meat weight) (g) & 590 & 695 & 550 & $611,66^{a}$ \\
\hline \multirow[t]{3}{*}{ (R2) } & $(\%)$ & 76,62 & 77,02 & 76,38 & $76,74^{n}$ \\
\hline & Bobot tulang (Bone weight) (g) & 135 & 160 & 120 & 138,33 \\
\hline & & 17,53 & 17,77 & 16,66 & 17,32 \\
\hline 15 & Bobot daging (Meat weight) (g) & 690 & 650 & 560 & $633,33^{2}$ \\
\hline \multirow{3}{*}{ (R3) } & $(\%)$ & 77,52 & 76,47 & 76,71 & $76,90^{2}$ \\
\hline & Bobot tulang (Bone weight) $(\mathrm{g})$ & 150 & 150 & 120 & 140 \\
\hline & $(\%)$ & 17,85 & 17,64 & 17,43 & 17,64 \\
\hline & Bobot daging (Meat weight) (g) & 760 & 730 & 770 & $753,33^{b}$ \\
\hline \multirow[t]{3}{*}{ (R4) } & $(\%)$ & 77,55 & 77,66 & 77,77 & $77,66^{b}$ \\
\hline & Bobot tulang (Bone weight) (g) & 160 & 155 & 165 & 160 \\
\hline & $(\%)$ & 16,33 & 16,49 & 16,66 & 16,49 \\
\hline
\end{tabular}

ab Huruf yang berbeda pada kolom yang sama menunjukkan perbedaan nyata $(\mathrm{P}<0,05)($ Different superscript in the same column showed significant difference $(P<0,05)$ ).

antara pasangan perlakuan lainnya berbeda tidak nyata. Hal ini menunjukkan bahwa pemberian konsentrat dalam pakan dengan level protein $18 \%$ merupakan yang terbaik untuk meningkatkan produksi daging maupun persentase daging karkas.

Bobot dan persentase tulang adalah relatif sama antar perlakuan diduga karena pertumbuhan tulang sudah stabil ketika mencapai umur saat peotongan. Hasil analisis statistik menunjukkan bahwa perlakuan berpengaruh tidak nyata. Tulang merupakan jaringan tubuh yang masak dini dan pertumbuhannya semakin lambat dengan meningkatnya umur (Cole dan Lawrie, 1974).

Kualitas fisik daging yang meliputi daya ikat air (DIA), susut masak (SM) dan keempukan (KP) tersaji dalam Tabel 3, menunjukkan bahwa DIA dan SM nyata dipengaruhi oleh level protein pakan yang 
Tabel 3. Rata-rata daya ikat air, susut masak dan kcempukan daging ( The average of water holding capacity, cooking loss, and tendeness of meat )

\begin{tabular}{|c|c|c|c|c|c|}
\hline \multirow{2}{*}{$\begin{array}{c}\text { Level protein } \\
\text { (Protein } \\
\text { level) }(\%)\end{array}$} & \multirow[t]{2}{*}{ Peubah (Parameter) } & \multicolumn{3}{|c|}{ Ulangan (Replication) } & \multirow{2}{*}{$\begin{array}{l}\text { Rata-rata } \\
\text { (Average) }\end{array}$} \\
\hline & & 1 & 2 & 3 & \\
\hline 9 & Daya ikat air (Water holding capacity) (\%) & 35,60 & 35,40 & 35,70 & $35,57^{\mathrm{a}}$ \\
\hline \multirow[t]{2}{*}{ (R1) } & Susut masak (Cooking loss) $(\%)$ & 34,50 & 34,00 & 34,40 & $34,30^{a}$ \\
\hline & Keempukan (Tenderness) $\left(\mathrm{kg} / \mathrm{cm}^{2}\right)$ & 2,80 & 2,70 & 2,70 & 2,73 \\
\hline 12 & Daya ikat air (Water holding capacity) $(\%)$ & 37,4 & 36,5 & 37,00 & $36,97^{\mathrm{b}}$ \\
\hline \multirow[t]{2}{*}{ (R2) } & Susut masak (Cooking loss) $(\%)$ & 33,40 & 33,20 & 33,00 & $33,20^{b}$ \\
\hline & Keempukan (Tenderness) $\left(\mathrm{kg} / \mathrm{cm}^{2}\right)$ & 2,60 & 2,60 & 2,50 & 2,57 \\
\hline \multirow{3}{*}{$\begin{array}{c}15 \\
\text { (R3) }\end{array}$} & Daya ikat air (Water holding capacity) (\%) & 38,50 & 38,80 & 38,60 & $38.63^{b}$ \\
\hline & Susut masak (Cooking loss) $(\%)$ & 33,00 & 33,20 & 33,20 & $33,13^{\mathrm{b}}$ \\
\hline & Keempukan (Tenderness) $\left(\mathrm{kg} / \mathrm{cm}^{2}\right)$ & 2,66 & 2,65 & 2,65 & 2,65 \\
\hline \multirow{3}{*}{$\begin{array}{c}18 \\
\text { (R4) }\end{array}$} & Daya ikat air (Water holding capacity) (\%) & 42,50 & 44,60 & 44,60 & $43,90^{b}$ \\
\hline & Susut masak (Cooking loss) $(\%)$ & 25,70 & 27,50 & 26,80 & $26,67^{b}$ \\
\hline & Keempukan (Tenderness) $\left(\mathrm{kg} / \mathrm{cm}^{2}\right)$ & 2,50 & 2,60 & 2,50 & 2,53 \\
\hline
\end{tabular}

a,b Huruf yang berbeda pada kolom yang sama menunjukkan perbedaan nyata $(\mathrm{P}<0,05)$. (Different superscript in the same column showed significant difference $(P<0.05)$.

diberikan sedangkan KP tidak dipengaruhi. Hasil penelitian menunjukkan perlakuan berpengaruh sangat nyata $(\mathrm{P}<0,01)$ terhadap DIA. Rata-rata DIA semakin tinggi seiring dengan peningkatan protein pakan. Diduga bahwa protein dalam daging semakin meningkat pula, karena protein bersifat mengikat molekul air. Di dalam daging terdapat 3 kompartemen air yang terikat yaitu 1) air yang terikat secara kimiawi oleh protein otot sebesar 4 - $5 \%, 2$ ) air yang terikat agak lemah dari molekul air terhadap grup hidrofilik sebesar $4 \%$ (kedua kompartemen air ini bebas dari perubahan molekul yang disebabkan oleh denaturasi protein daging), 3) molekul air bebas diantara molekul protein sebesar $10 \%$ (Soeparno, 1992).

DIA berhubungan dengan besarnya ukuran daging dan struktur jaringan daging tersebut (Lawrie, 1979). Daging dengan ukuran yang kecil struktur jaringannya sudah dirusak menyebabkan rendahnya kemampuan menahan cairan yang keluar atau yang dibebaskan dari protein sebab hampir semua air dalam urat daging berada dalam miofibril, dalam ruang antara filamen yang tebal dari miosin dan filamen yang tipis dari aktin atau tropomiosin. Hasil uji Duncan menunjukkan bahwa pasangan perlakuan R4 - R3, R4 - R2, R4 - R1 berbeda nyata sedangkan antara perlakuan lainnya berbeda tidak nyata. Keadaan ini menunjukkan bahwa pemberian pakan kelinci dengan level protein sampai dengan $18 \%$ memberikan hasil yang baik pada daya ikat air daging.

Hasil penelitian menunjukkan bahwa perlakuan berpengaruh sangat nyata terhadap SM daging kelinci. SM semakin menurun dengan meningkatnya level protein pakan. SM berhubungan dengan DIA dimana DIA meningkat maka SM menurun dan sebaliknya (Soeparno, 1992). Uji Duncan menunjukkan bahwa pasangan perlakuan $\mathrm{R} 1$ - R2, R1 - R3, R1 - R4 berbeda nyata sedangkan antar perlakuan lainnya berbeda tidak nyata. Tingkat keempukan daging secara relatif adalah sama dan tidak dipengaruhi oleh adanya perlakuan. Banyak faktor yang dapat mempengaruhi tingkat keempukan daging antara lain sifat struktur, kekuatan tenunan pengikat, status kontraksi miofibril serta tipe urat daging (Lawrie, 1979; Soeparno, 1992).

\section{Kesimpulan}

Produksi karkas yang ditunjukkan oleh bobot karkas, bobot dan persentase daging meningkat dengan meningkatnya level protein pakan. Bobot dan persentase daging lebih tinggi dari bobot dan persentase tulang, sedangkan 
persentase tulang secara relatif adalah sama. Kualitas fisik daging yaitu DIA meningkat dengan meningkatnya level protein pakan, SM cenderung menurun dengan meningkatnya level protein pakan sedangkan keempukan tidak berbeda antar perlakuan.

\section{Daftar Pustaka}

Anggorodi, R., dan Wahyu. 1969. Pengantar Ilmu Makanan Ternak. Direktorat Peternakan Rakyat, Direktorat Jenderal Peternakan, Departemen Pertanian. Jakarta,

Arrington, I., and K. C. Kelley, 1976. Domestic Rabbits Biology and Production. The University Press of Florida, Gainneaville.

Blakely, J. dan D. H. Bade. 1991. Ilmu Peternakan. Edisi ke Empat. Terjemahan Bambang Srigandono. Gadjah Mada University Press. Yogyakarta.

Calvert, J. 1973. Commercial Rabbits Production. Bul. No. 50. 9th. ed. Ministry of Agriculture Fisheries and Food, London.

Cassady, R. B., P. B. Sawin and J. Vandam. 1971. Commercial Rabbit Raising. US. Dept. of Agr. Hand Book No. 309
Cole, D. J. A. dan R. A. Lawrie. 1974. Meat. Butterworth, London.

Lawrie, R. A. 1979. Meat Science. $3^{\text {nd }}$. ed. Pergamon Press, Oxford.

Prawirokusumo, S. 1993. Ilmu Gizi Komparatif. BPFE - Yogyakarta.

Rasyaf, M. 1994. Beternak Ayam Pedaging. Penebar Swadaya. Jakarta.

Rismunandar. 1986. Meningkatkan Konsumsi Protein Dengan Beternak Kelinci. CV. Sinar Baru, Bandung.

Sents, A. E., L. E. Walters and J. V. Whiteman. 1982. Performance and Carcass Characteristics of Ram Lambs Slaughtered Different Weights. J. Anim. Sci. $6: 1360$.

Soeparno. 1992. Ilmu dan Teknologi Daging. Cetakan I. Gadjah Mada University Press. Yogyakarta.

Sofyadi, E. 1984. Pertumbuhan pada Ternak Kelinci dan Berbagai Faktor yang Mempengaruhinya. Fakultas Peternakan IPB, Bogor.

Steel, R. G. D. and J. H. Torrie. 1993. Prinsip dan Prosedur Statistika, Suatu Pendekatan Biometr̂ik, Edisi ke Tiga. Alih Bahasa, B. Sumantri. Gramedia Pustaka Utama, Jakarta. 